\title{
В.А. Овчинников
}

\section{КАЗАХСТАНСКАЯ МОДЕЛЬ ЭТНОКОНФЕССИОНАЛЬНОГО СОГЛАСИЯ}

\begin{abstract}
Изложены результаты исследования общих тенденций и особенностей создания и функционирования модели этноконфессионального согласия в Казахстане. Источниковую базу исследования составил комплекс опубликованных «открытых» источников: нормативно-правовых актов, программных и распорядительных документов, документов делопроизводства, методических рекомендаций органов государственной власти и религиозных организаций, статистических отчетов, материалов светской и церковной периодической печати. Разработка особой модели была обусловлена угрозой социополитической стабильности, резким изменением этнорелигиозной структуры населения в постсоветское время, многонациональным и многоконфессиональным характером государства. Изменения в политической жизни государства, происходящие в 2019 г., станут серьезной проверкой модели на жизнеспособность и эффективность

Ключевые слова: этноконфессиональное согласие; модель; поликонфессиональность; Казахстан; ислам; Русская православная церковь.
\end{abstract}

После распада СССР в Казахстане, как и в большинстве бывших союзных республик, усилился интерес граждан к религии. Культурно-духовная жизнь и общественно-политические процессы базировались не только на отрицании всего, связанного с Советским Союзом и коммунистической идеологией, но и на негативном отношении ко «всему русскому».

На этапе становления нового государства произошло существенное изменение этнической структуры населения. С 1989 по 2018 г. доля этнических казахов, проживающих на территории республики, возросла с менее 40 до почти 70\%. При этом общая численность населения увеличилась с 16,5 до 18 млн человек, а русское население сократилось с 6227 тыс. человек в 1989 г. до 3588 тыс. человек на 1 апреля 2018 г. По приблизительным данным, с 1989 по 2003 г. около 1,3 млн русских перебрались из Казахстана в Российскую Федерацию [1].

Перед новым независимым государством остро стояли задачи укрепления национального и духовного единства граждан, недопущения «политизации религии» в процессе возрождения ислама. Методом проб и ошибок у государства и общества формировалось представление о модели государственноконфессиональных отношений, о механизмах поддержки возрождения ислама и религиозных традиций при сохранении курса на коренные общественнополитические преобразования и строительство светского современного государства.

Президент Н.А. Назарбаев рассматривал усиление роли религии и поликонфессиональность общества как положительный фактор для укрепления единства многонационального государства. Он взял курс на создание «системы диалога конфессий» для сохранения межконфессионального согласия в Казахстане и вывода религии за границы локальной и глобальной «политической игры» [2. С. 163, 215; 3. С. 212].
В конце XX в. ислам в регионе возродился и на его основе во многих государствах были сделаны попытки сформировать новую культурно-ценностную систему. При этом мусульманские общины Центральной Азии стали развиваться и налаживать связи вне государственного контроля и границ. Процесс либерализации религиозной сферы жизни привел к росту адептов как радикальных течений ислама, так и нетрадиционных для Казахстана религий [4. С. 8; 5. С. 8; 6].

В зоне особого риска оказалась молодежь 1429 лет, которая в Казахстане составляет почти треть от общей численности населения. Доля религиозной настроенной молодежи с 2003 по 2015 г. выросла с 38,7 до 74\%. Духовные поиски молодых людей, их интерес к религии использовали многочисленные «нетрадиционные» религиозные организации, которые появились в республике. Согласно опросам, каждый десятый религиозно настроенный человек был готов защищать интересы своей религиозно-этнической группы с оружием в руках. «Ослабленность» традиционных религиозных конфессий, низкая правовая и религиозная грамотность молодежи, высокий уровень агитационной активности и финансовой поддержки «нетрадиционных» религиозных организаций в совокупности с развитием информационных технологий являлись факторами, которые способствовали развитию «нетрадиционных» религиозных течений в Казахстане» [7].

Новое законодательство Республики Казахстан (далее - РК) в религиозной сфере было либеральным и несовершенным. Устанавливалось равенство всех религий, был провозглашен принцип невмешательства государства в дела религиозных объединений. Деятельность религиозных объединений регламентировалась Конституцией, Гражданским кодексом и Законом Республики Казахстан 1992 г. «О свободе исповедания и религиозных объединений» (утратил силу в соответствии с законом РК от 11.10.2011 № 483-IV), а также рядом нормативных актов [8-10]. 
Несовершенство законодательства, отсутствие механизмов контроля государства на стадии построения новой модели межконфессионального согласия привели к нерегулируемому росту верующих и религиозных объединений, получавших поддержку из-за рубежа, притоку иностранных миссионеров и создали основу для вовлечения граждан, особенно молодежи, в деструктивные религиозные движения. Комитет национальной безопасности отмечал увеличение числа иностранных религиозных миссий, посещающих республику с целью распространения «новых» религиозных учений, что создавало предпосылки для конфликтов на религиозной и этнической почве [11]. В Казахстане начали открываться неофициальные духовные учебные заведения. Только в Жамбыльской и Южно-Казахстанской областях действовало свыше 20 таких заведений, не имеющих лицензии на образовательную деятельность.

Не помогло взять ситуацию под контроль и образование в январе 1990 г. Духовного управления мусульман Казахстана (далее - ДУМК), которое возглавил муфтий Ратбек-кажи Нысанбайулы, а с июня 2000 г. Абсаттар-кажи Дербисали (ныне директор Института востоковедения Комитета науки Министерства образования и науки РК). Официальные исследователи оценивают ДУМК как институт, занимающийся государственно-исламскими отношениями, межрелигиозным диалогом, международными связями мусульманской общины, который наряду с традиционными формами начал «формирование новообразований» в мусульманской среде: женских, молодежных и других общественно-политических, благотворительных неправительственных организаций [12. С. 10]. Но при этом с момента создания ДУМК подвергается резкой критике со стороны различных представителей мусульманских общин: от обвинений в полном контроле и подчинении государству до пособничества в распространении радикальных идей.

Мусульманская община Республики Казахстан неоднородна, и принадлежность разных этнических групп к одной конфессии не привела к нейтрализации межэтнических противоречий. Помимо казахов, мусульманскую общину представляют еще 17 этнических групп: узбеки, татары, уйгуры, таджики, курды, дунгане, чеченцы, ингуши и др. Противоречия между ними приводили к открытым столкновениям не только в конце XX в. За 2003-2006 гг. почти вдвое возросло количество бытовых конфликтов на религиозной почве [2. C. 275].

На этом фоне выделялось отсутствие открытых конфликтов казахов с представителями славянских народов и немцами. В этой ситуации государственная власть понимала, что ей необходимо заручиться поддержкой традиционных христианских религиозных организаций. В первую очередь, обеспечить лояльность русского населения, а также замедлить миграцию русских из Казахстана. Это должно было стать основой для построении устойчивой модели межконфессио- нального и межнационального согласия. Как правило, казахи являлись представителями мусульманской общины, русские - православной, немцы, в основном, являются адептами протестантских общин, а также католической церкви, как поляки и литовцы.

С первых лет создания нового государства президентом Н.А. Назарбаевым был взят курс на построение модели этноконфессионального согласия. Было провозглашено равенство всех этносов, возрождение и развитие их языков и культуры. Особой чертой казахстанской модели этноконфессионального согласия стала система постоянного взаимодействия светского государства и религиозных организаций по всем важным вопросам общественно-политического развития. Функционирование модели этноконфессионального согласия Республики Казахстан регулируется Конституцией и рядом правовых актов, в которых предоставляются равные права всем религиозным объединениям и отмечается независимость государства и религиозных организаций в рамках правового поля.

С 1993 г. в Казахстане началась последовательная работа по совершенствованию нормативно-правовой основы и созданию структур, обеспечивающих взаимодействие государства и религиозных организаций. В 1993 г. по инициативе президента Н.А. Назарбаева в Конституцию было внесено положение, предусматривающее запрет деятельности общественных и религиозных организаций, провозглашающих или на практике реализующих религиозную нетерпимость. Это положение было закреплено и в ст. 53 Конституции 1995 г. [810]. Новые положения, регламентирующие деятельность миссионеров, зарубежных руководителей религиозных объединений и духовных учебных заведений, были внесены в Гражданский кодекс [13].

В 1995 г. для совершенствования реализации государственной национальной политики был создан консультативно-совещательный орган при президенте Казахстана - Ассамблея народов Казахстана (с 2007 г. Ассамблея народа Казахстана). С 1996 г. в стране начал функционировать Совет по делам религии при президенте. Вопросы координации связей с религиозными организациями стали решаться в рамках Министерства информации и общественного согласия. Государство усилило поддержку официальных мусульманских религиозных объединений [14].

Но отсутствие контроля над процессом религиозного возрождения, угроза развития политикорелигиозных течений подтолкнули государство к усилению контроля над религиозной сферой. Указ президента Казахстана «О мерах по предупреждению и пресечению проявлений терроризма и экстремизма» (от 10 февраля 2000 г.) был направлен против радикализации религиозного сознания граждан, подрыва межэтнического и межконфессионального согласия [15]. Поводом для этих мер послужили отчасти теракты в г. Ташкенте 16 февраля 1999 г., целью которых являлись правительственные объекты. 
В 2003-2005 гг. государственная власть предприняла ряд знаковых мер, к которым относится и утверждение на законодательном уровне в качестве выходных дней в 2005 г. первого дня Курбан айта, отмечаемого по мусульманскому календарю, и Православного Рождества (7 января). В июне 2005 г. в г. Астане были проведены торжественные мероприятия, посвященные 150-летнему юбилею со дня открытия и освящения Константино-Еленинского кафедрального собора.

На этом этапе в Казахстане окончательно сложилось понимание того, как должна выглядеть модель этноконфессионального согласия. Президент Казахстана заявил, что в центре сложной модели межрелигиозной конфигурации «находятся наиболее крупные религии Казахстана - ислам и православие, которые в своем взаимодействии и обеспечивают, по существу, межрелигиозную стабильность в стране» [13. С. 268]. При посещении 7 января 2012 г. Свято-Успенского собора в г. Астане он сказал: «Как птица не может летать с одним крылом, так и государство не может двигаться с одним крылом. Оба крыла - ислам и православие основные религиозные конфессии в нашей стране. Все мы люди, единые на этой Земле, но мы разные по языку, внешнему виду и религии. Но великое терпение всегда является основой для мирной жизни». В основу государственного устройства страны был положен принцип «формирования идентичности на базе гражданства, а не этнических и религиозных признаков» [16. C. 26].

Государство, заручившись поддержкой традиционных конфессий, стало ускоренно внедрять в жизнь модель этноконфессионального согласия. Об этой модели неоднократно в своих выступлениях заявлял президент и представители государственной власти, характеризуя ее как признанную во всем мире и известную как «Казахстанский путь», или «Казахстанская модель». Н. Назарбаев отмечал, что ее успех обусловлен особенностями истории Казахстана и его народа, а развитие межконфессионального согласия основано на процессах многовекового взаимопроникновения различных культурноцивилизационных типов на этой территории [17].

Русской православной церкви (далее - РПЦ) в Казахстане было отведено особое место в создаваемой модели этноконфессионального согласия. Православная церковь имеет на территории Казахстана двухвековой опыт работы и получила организационное оформление еще в второй половине XIX в.: в 1871 г. была учреждена Туркестанская епархия. Несмотря на гонения в советский период, в 1945 г. была образована Алма-Атинская и Казахстанская епархия, которую возглавил митрополит Николай (Могилевский). С этого времени начался постоянный рост количества приходов РПЦ на территории Казахстана. Если в 1956 г. в Казахстане функционировало 55 приходов, то в начале 1999 г. -212 приходов и 8 монастырей. И это несмотря на значительную миграцию русского населения.
С первых лет строительства независимого государства президент Казахстана сделал ряд важных шагов, обозначивших роль, место Русской православной церкви и отношение к ней государственной власти. В 1995 г. церкви был передан Вознесенский кафедральный собор в г. Алматы, являющийся памятником архитектуры. Начался процесс передачи храмов православным общинам в других городах республики. Казахстан принял участие в строительстве собора Христа Спасителя в Москве, подарив гранит Кордайского месторождения для отделки стен.

Для улучшения церковной работы в 1991 г. из бывшей единственной на территории Казахстана АлмаАтинской епархии были выделены самостоятельные Уральская и Чимкентская епархии. В 2003 г. по решению Синода был образован Митрополичий округ с центром в г. Астане, объединивший три епархии (Астанайскую, Уральскую, Чимкентскую) на территории Казахстана.

2010-й год - очередная веха в укреплении позиций РПЦ в Казахстане. Синод определил новый статус Казахстанской митрополии как нового канонического подразделения РПЦ, наделенного значительными правами самостоятельности - Митрополичьего округа в Республике Казахстан (Православной церкви Казахстана). До октября 2010 г. Митрополичий округ включал в себя три епархии с центрами в городах Астане, Чимкенте и Уральске. В 2010-2011 гг. были созданы шесть новых епархий, а с 2011 г. в состав Митрополичьего округа входят девять епархий: Астанайская, Карагандинская, Кокшетауская, Костанайская, Павлодарская, Петропавловско-Булаевская, Уральская, УстьКаменогорская, Чимкентская. По итогам перерегистрации, по состоянию на 25.10.2012, в Казахстане действовало 271 религиозное объединение Русской православной церкви, включая республиканское религиозное объединение - Митрополичий округ, а также 9 епархий и 261 приход. Наибольшее количество православных общин зарегистрировано в Алматинской, ВосточноКазахстанской, Северо-Казахстанской, Костанайской, Карагандинской и Акмолинской областях.

5 марта 2010 г. митрополитом Астанайским и АлмаАтинским и главой округа был назначен архиепископ Александр (Могилёв). Митрополит Александр прошел долгий путь служения в РПЦ. В 1990 г. окончил Московскую духовную академию со степенью кандидата богословия. Иерарх умело представлял интересы церкви в органах государственной власти и общественных объединениях и, что чрезвычайно важно, в сложных ситуациях находил общий язык и работал сообща как с государственными чиновниками, так и с представителями различных общественных сил, религиозных организаций, национальных объединений. 28 июня 2010 г. он был возведен в сан митрополита. 20 октября 2010 г. вошел в состав Совета Ассамблеи народа Казахстана. 26 июля 2011 г. введен в состав Комиссии по правам человека при Президенте РК. Решением Синода от 5- 
6 октября 2011 г. был назначен постоянным членом Синода РПЦ. Наряду с многочисленными церковными и российскими орденами, заслуги митрополита Александра отмечены государственными наградами Казахстана: 2012 г. - орден Почета (Республика Казахстан); 2015 г. - медаль «20-летие Ассамблеи народа Казахстана»; 2017 г. - орден «Парасат» («Благородство») [18].

На протяжении 2000-2018 гг. Православная церковь Казахстана неизменно позиционировала себя как надежного партнера государства. Церковь стала незаменимым элементом действующей модели государственноконфессиональных отношений РК, участвовала в обсуждении и акциях поддержки новых реформ [19].

Патриархи Алексей и Кирилл лично взаимодействовали с президентом Казахстана и принимали участие в решении всех существенных проблем церкви в Казахстане. Патриарх Кирилл постоянно подчеркивает особую роль президента Казахстана в поддержании мира в казахском обществе и на постсоветском пространстве в целом, выдающийся личный вклад в развитие отношений с Россией. Во время визитов патриарха в Казахстан традиционной составляющей официальных мероприятий стали его встречи с президентом Н. Назарбаевым. 21 декабря 2015 г. в Москве патриарх Кирилл наградил президента Н.А. Назарбаева орденом Сергия Радонежского I степени за развитие отношений между Казахстаном и РПЦ и в связи с 75-летием со дня рождения [20, 21].

Президент Казахстана выработал особый механизм взаимодействия с РПЦ. Ни один религиозный и исторический праздник или крупное событие в жизни РПЦ не были обделены вниманием Н.А. Назарбаева. Так, в его приветствии участникам Архиерейского собора РПЦ 2017 г., посвященного 100-летию восстановления патриаршества и 100-летию Поместного собора 1917 1918 гг., отмечалось: «Православное христианство в истории суверенной Республики Казахстан занимает важное место и вносит значительный вклад в укрепление межконфессионального мира и межэтнического согласия в обществе. Уверен, что решения, принятые архипастырями Русской православной церкви, послужат утверждению мира и гражданского согласия, поддержанию добрых отношений с государствами и народами, связанными общей историей и культурой» [21].

К 2017 г. Митрополичий округ РПЦ в РК состоял из 9 епархий, 355 приходов, в которых служили около 700 священнослужителей и 11 архиереев. Духовная семинария была открыта в 2010 г. на базе созданного в 1991 г. епархиального духовного училища в г. Алматы. В Астанайской и Алма-Атинской епархии действовало 2 женских монастыря (Иверско-Серафимовский монастырь в г. Алматы, монастырь в честь иконы Божьей Матери «Взыскание погибших» в г. Астане) и 2 мужские пустыни (в городах Каскелен и Иссык Алма-Атинской области).

Православная церковь Казахстана стала неотъемлемой и важной частью организационной основы казахстанской модели этноконфессионального согласия. Это положение церкви позволило ей стать одной из точек развития Республики Казахстан.

Результаты исследования подтверждают и уточняют следующие положения, сформулированные при оценке разных аспектов изучаемой проблемы политиками, религиозными деятелями, учеными-политологами, религиоведами, социологами, историками:

1. Положение РПЦ в Казахстане напрямую зависит от отношения правящих элит, которое выражается посредством государственной конфессиональной политики.

2. Отношение правящих элит к РПЦ в значительной степени зависит от внутреннего состояния государств и степени влияния на его стабильность религиозного и национального факторов.

3. На отношение правящих элит к РПЦ и механизмы реализации государственной конфессиональной политики во многом влияет степень развития и напряженности межгосударственных отношений между Казахстаном и Россией, а также позиция Президента и Правительства РФ по отношению к структурам РПЦ в Казахстане.

4. На положение РПЦ существенно влияет отношение представителей «титульной нации» и основных религиозных конфессий.

5. РПЦ в Казахстане в основном опирается на русское население, представители которого составляют большую часть исповедующих православие и адептов РПЦ.

6. РПЦ в Казахстане является инструментом поддержки русского населения, распространения русской культуры и языка, так называемым русским фактором влияния, из-за чего пользуется неизменной поддержкой со стороны руководства Российской Федерации.

7. Казахстан является светским государством, рассматривающим межконфессиональное и межэтническое согласие как необходимое условие целостности и развития государства. Государственная политика направлена на поддержку мирного взаимодействия представителей различных национальностей и религиозных конфессий, что благотворно отражается на положении РПЦ в Казахстане.

8. Руководство Казахстана успешно пытается использовать РПЦ во внутренней политике как инструмент модернизации действующей модели межэтнического и межконфессионального согласия в государстве, а также во внешней политике как одну из точек укрепления добрососедских отношений с Россией.

9. Существует большая вероятность ограничения прав русского населения и изменения отношения к РПЦ со стороны правящих элит в случае победы оппозиционных партий, чья идеология основана на «казахской национальной идее» (или идее «этнокультурного национализма»).

Несмотря на последовательное построение светского государства, в Казахстане в 2000-2010 гг. наблюдался рост как традиционных, так и новых для региона религиозных организаций. Например, количество зарегистрированных исламских объединений с 1991 по 2013 г. 
увеличилось с 68 до 2756 , а за этот же период количество объединений РПЦ выросло с 87 до 303. На фоне роста количества исламских и православных объединений из-за изменения миграционных процессов и религиозного законодательства значительно сократилось количество лютеранских и баптистских объединений [22]. Их место начали занимать различные «нетрадиционные» деноминации, или «секты», отношение к которым у населения было достаточно противоречивым.

Протестные события 2011 г. в Казахстане показали необходимость модернизации механизма регулирования религиозной сферы. Государство пошло на усиление контроля за религиозной сферой, развитие этноконфессионального взаимодействия для объединения усилий по достижению общенациональной цели. Это привело к росту количества религиозных объединений и изменению религиозной структуры. Если на 1 января 2004 г. в Казахстане действовало 3157 религиозных объединений, то в 2011 г. - уже 4551 религиозное объединение. Стремительный рост религиозных объединений в основном был обеспечен развитием мусульманских общин. За 1991-2013 гг. количество мусульманских объединений возросло более чем в 40 раз, православных - только в 3,5 раза. Если в начале 2000 -х гг. в Казахстане действовало только 1 652, то в ноябре 2015 г. уже 2482 мусульманских культовых сооружения [23. С. $11 ; 24$. С. $234 ; 25 ; 26]$.

Одновременно произошел рост структур Русской православной церкви: в начале 1999 г. - 212 приходов и 8 монастырей, в ноябре 2015 г. - 320 религиозных субъектов, 289 культовых сооружений. Кроме Русской православной церкви, в Казахстане действовали Армянская апостольская церковь, Православная церковь за рубежом, четыре церкви старообрядческого направления [23. С. 15].

На территории Казахстана активно развивались и иные христианские церкви. Римская католическая церковь с центром в г. Караганде укрепила свои позиции после открытия в 1998 г. духовной семинарии, визита в республику в сентябре 2001 г. Папы Римского и создания в мае 2003 г. католической митрополии на территории Казахстана. Деятельность протестантских конфессий развивалась более медленными темпами в связи с массовым отъездом в Германию этнических немцев. Эту нишу успешно заняли пресвитерианские церкви, созданные иностранными миссионерами при поддержке из-за рубежа. Так, до принятия Закона «О религиозной деятельности и религиозных объединениях» (2011 г.) в республике действовало 229 таких религиозных объединений, после его принятия в 2015 г. - 107.

К моменту принятия нового закона в 2011 г. в Казахстане было зарегистрировано 32 конфессии и более 20 деноминаций. Всего они составляли 4430 религиозных объединений и групп, 3839 из которых были зарегистрированы как юридические лица или филиалы. Все эти религиозные объединения владели и пользовались 3369 культовыми сооружениями. Самыми много- численными были исламские конфессии и деноминации (2 756) с 2416 культовыми сооружениями. Из них суннитские организации составляли абсолютное большинство - 2740 с 2408 культовыми сооружениями. Второй по количественным показателям была Русская православная церковь: 291 организация, зарегистрированная как юридическое лицо, и 261 культовое сооружение. Остальные церкви православного толка не могли составить ей конкуренции: Армянская апостольская церковь (1 организация), Православная церковь за рубежом (2 организации, 1 культовое сооружение), 4 церкви старообрядческого направления (9 организаций, 7 культовых сооружений). Римская католическая церковь была представлена 82 юридическими лицами и 86 культовыми сооружениями.

После принятия Закона 2011 г. «О религиозной деятельности и религиозных объединениях» в течение 2012 г. количество религиозных объединений сократилось до 3 088, представляющих всего 17 конфессий. Из 666 протестантских религиозных объединений прошли перерегистрацию всего 462, а 204 подали на ликвидацию. Из 48 «нетрадиционных объединений» перерегистрировались только 16, а 32 были ликвидированы.

После изменения законодательства Комитет по делам религий Министерства культуры и спорта Республики Казахстан развернул масштабную профилактическую работу с молодежью. Для государственных служащих также были разработаны методическое пособие и образовательные программы [27].

В течение нескольких месяцев произошли изменения в управлении религиозной сферой. Комитет по делам религий при Министерстве культуры и спорта Казахстана был упразднен, и его функции и полномочия перешли образованному 18 мая 2011 г. Агентству Республики Казахстан по делам религий, которое стало центральным исполнительным органом, осуществляющим государственное руководство в сфере обеспечения межконфессионального согласия, прав граждан на свободу вероисповедания и взаимодействия с религиозными объединениями.

В Законе 2011 г. «О религиозной деятельности и религиозных объединениях» признавалась историческая роль не только ислама ханафитского направления, но и православного христианства в развитии культуры и духовной жизни народа. Закон подтвердил, что в Казахстане никакая религия не может устанавливаться в качестве государственной и обязательной, а система образования носит светский характер и отделена от религии и религиозных объединений [28].

В процессе усиления роли государства в регулировании религиозной деятельности и в рамках внедрения модели этноконфессионального согласия была сформирована новая правовая база, проведена перерегистрация религиозных объединений, введена новая структура (местные, региональные и республиканские) и классификация религиозных объединений (17 конфессий вместо 46 конфессий и деноминаций), создана 
система регулирования миссионерской и духовнообразовательной деятельности [29].

В результате реформы была создана единая исламская организация, которая проповедует исламскую веру суннитского направления с учетом исторических особенностей ислама на территории республики. Официальный ислам продолжило представлять Духовное управление мусульман Казахстана. С этого времени структуры Русской православной церкви в Республике Казахстан представители государственной власти стали называть Православной церковью Казахстана.

По данным Министерства по делам религий и гражданского общества, на 20 апреля 2011 г. в Казахстане было зарегистрировано 3679 религиозных объединений (2 570 мусульманских, 333 православных, 85 католических, 668 протестантских, 7 иудейских и 17 других), представляющих 18 конфессий. Если сравнивать количество религиозных организаций на 20 апреля 2017 г. с данными на 1 января 2011 г., то видна тенденция уменьшения исламских организаций (с 2756 до 2 570) и рост православных (с 303 до 333). Количество католических организаций (вместе с униатами) сократилось с 87 до 85 .

На 1 октября 2016 г. было зарегистрировано 3436 культовых сооружений, из них: 2528 мечетей, 294 православные церкви, 108 католических костелов, 490 протестантских храмов и молитвенных домов, 7 иудейских синагог, 2 буддийских культовых сооружения, 3 молитвенных дома Общества сознания Кришны, 4 молитвенных дома бахаи. В Казахстане в 2017 г. действовало 495 зарегистрированных миссионеров. Среди них преобладали католики - 238, а православие представляли 87 миссионеров, большинство из них граждане России [30, 31].

В 2012-2018 гг. наблюдалось увеличение количества филиалов ДУМК не только в южных, но и в северных и восточных областях Казахстана, где традиционно сильными были позиции РПЦ. Это произошло изза миграции русского населения, низкого уровня его религиозности и активизации деятельности ДУМК, особенно в Алма-Атинской, Джамбульской, Карагандинской и Южно-Казахстанской областях. ДУМК поддерживало русскоязычную группу проповедников для русскоязычных мусульман в северных областях Казахстана. Среди русскоязычных религиозных лидеров есть богословы и имамы с религиозными знаниями и светским образованием. Велись курсы на русском языке, на сайте вся информация также всегда была представлена на русском языке [32].

РПЦ не предпринимает активных действий по обращению в православную веру этнических казахов. Это негативно воспринимается этнической и мусульманской общинами, региональными властями. Религиозную принадлежность значительная часть казахов воспринимает в основном как традиционный идентификационный критерий. При этом на бытовом уровне они часто участвуют в христианских обрядах. Например, в крещенских купаниях в освященной проруби.

Данные Национальной переписи населения 2009 г. позволяют оценивать Казахстан как государство, входящее в список 15 стран мира, имеющих наибольшую численность православного населения. И, очевидно, занимающее первое место среди стран, находящихся не в Европе, или среди государств с явным преобладанием последователей ислама [33]. Исторический опыт межэтнического и межконфессионального взаимодействия, активное участие России и РПЦ в формировании национальной культуры и интеллигенции на протяжении нескольких веков делает православие привлекательным для представителей интеллигенции и городского населения. Этнические казахи служат православными священниками в Алма-Ате, Караганде и других городах.

Численность населения Казахстана на 1 июля 2017 г. составляла 18034400 человек. Этническая структура общества согласно национальной Переписи 2009 г. была следующей: казахи - 63,07\%, русские $23,70 \%$, узбеки - 2,85\%, украинцы - 2,08\%, уйгуры $1,40 \%$, татары - 1,28\%, немцы $-1,11 \%$, другие $-4,51$ \%. В Казахстане проживало 130 этносов. Этническая структура общества обусловила его религиозную структуру. Основные типы религиозной самоидентификации граждан связаны с исламом и христианством. Традиционно самыми многочисленными среди них являются ислам ханафитского мазхаба и православное христианство. 81\% граждан республики считают себя верующими, 19\% - атеистами и агностиками. Из числа верующих только 14\% относят себя к практикующим верующим, а около 70\% - к умеренным (не практикующим) верующим [34].

Несмотря на последовательные меры, предпринятые после 2011 г., ситуация в политической и религиозной сфере обострилась в 2015-2016 гг. В сложные внутренние межконфессиональные процессы стали вмешиваться другие государства. В декабре 2015 г. президент Н. Назарбаев призвал правительство сделать все, чтобы не дать гражданам Казахстана пасть «под влиянием чужеродных ложных идеологий и призывов радикально настроенных проповедников, которые недавно посетили нас, чтобы вербовать людей для незаконных и бесчеловечных действий».

После попытки «государственного переворота» в Республике Казахстан в 2016 г. и повышения уровня террористической опасности последовали дальнейшие меры по «ужесточению» «религиозного» законодательства. Позиция государства была отражена в двух основных документах: Государственной программе по противодействию религиозному экстремизму и терроризму в Республике Казахстан на 2013-2017 гг. и Концепции государственной политики в религиозной сфере Республики Казахстан на 2017-2020 гг. [35, 36].

В сентябре 2016 г. президентским указом было создано Министерство по делам религий и гражданского общества. Председателем Комитета по делам религий 
Министерства по делам религий и гражданского общества РК с ноября 2017 г. был назначен Н. Ермекбаев, прошедший долгий путь службы в силовых структурах и сфере образования. Действия Н. Ермекбаева были оценены экспертами как жесткие, а все законодательные инициативы как ограничительные. Сразу после создания министерства были подписаны соглашения с ДУМК и РПЦ, объединяющие большую часть верующего населения страны. Была разработана и 20 июня 2017 г. Указом Президента Казахстана утверждена Концепция государственной политики в религиозной сфере РК на 2017-2020 гг., направленная на дальнейшее усиление государственного контроля за религиозной сферой. После принятия концепции было внесено 60 поправок в 17 законодательных актов, направленных на укрепление светских принципов развития государства, был разработан законопроект «О внесении изменений и дополнений в некоторые законодательные акты Республики Казахстан по вопросам религиозной деятельности и религиозных объединений», создана межведомственная комиссия по координации государственной политики в религиозной сфере. В региональных центрах исследования проблем религий были образованы специальные отделы реабилитации граждан, попавших под влияние деструктивной и радикальной идеологии. В Казахстане действовало 249 специальных теологических и информационных групп, в их составе около 3,5 тыс. человек. Только в 2017 г. было проведено около 23 тыс. мероприятий с охватом 1 млн 850 человек. За полгода было разработано 50 методических рекомендаций, для 3 тыс. лекторов провели обучающие курсы. Для просветительской работы были задействованы телеканалы и интернет-сеть [37; 38. С. 110-121]. Началась разработка школьного учебника «Общество и религия», было открыто обучение по специальности «религиоведение» в вузах Южно-Казахстанской, Западно-Казахстанской, Жамбылской, Кызылординской и Восточно-Казахстанской областей.

После проведения реформ, которые вызвали напряжение даже у представителей традиционных конфессий, и достижения запланированных результатов Н. Ермекбаев перешел на должность секретаря Совета безопасности РК. 4 апреля 2018 г. его на посту министра по делам религий и гражданского общества сменил депутат Сената Казахстана Д. Калетаев. Было решено применить более «мягкие» подходы к регулированию религиозной сферы. Министерство по делам религий и гражданского общества было переименовано в Министерство общественного развития.

Перед принятием Концепции и законопроекта «О религиозной деятельности и религиозных объединениях» было устроено обсуждение проекта. В нем участвовали представители ДУМК, Православной церкви Казахстана и иных конфессий. В ходе обсуждений первоначальный вариант, который, по оценкам религиозных организаций, серьезно ограничивал миссионерство, образовательную деятельность и работу с молодежью, удалось «смягчить». О «жесткости» проекта свидетельствует и тот факт, что для контроля за хозяйственнофинансовой деятельностью предполагалось установить кассовые аппараты в культовых зданиях.

29 января 2018 г. Министерство по делам религий и гражданского общества представило проект Закона «О внесении изменений и дополнений в некоторые законодательные акты Республики Казахстан по вопросам религиозной деятельности и религиозных объединений» в Мажилисе Парламента РК. Закон направлен на совершенствование государственно-конфессиональных отношений, уточнение прав и обязанностей субъектов религиозной деятельности. Документ предполагал внесение 53 изменений и дополнений в 12 законодательных актов. Это должно было еще более повысить контроль государства за религиозной сферой. Законодательно впервые были введены юридические определения понятий «деструктивное религиозное течение» и «религиозный радикализм». Правовое регулирование коснулось религиозного образования за рубежом, поведения госслужащих и работников бюджетных организаций в религиозной сфере, участия несовершеннолетних в богослужениях и обрядах. Были введены нормы по обеспечению прозрачности финансовой деятельности религиозных объединений.

Государственную конфессиональную политику в Республике Казахстан можно признать успешной, если в качестве результата рассматривать построение казахстанской модели этноконфессионального согласия. Ее внедрение сопровождалось переходами от «жестких» к более гибким механизмам и формам контроля в религиозной сфере. Перед руководством Казахстана стоит сложная задача обеспечения развития государства и общества и формирования новой граждансконациональной идентичности с опорой на традиционную культуру и религию, в первую очередь - на ценности ислама, искоренение радикальных сил, разрушающих межэтническое и межрелигиозное согласие.

По официальным данным, в Казахстане примерно 75\% населения считают себя верующими, межэтническую ситуацию позитивно оценивают 94,9\% граждан, 94,5\% ощущают себя представителями единого народа Казахстана. Государственная политика в сфере межэтнических отношений пользуется поддержкой 95,7\% граждан, и уровень толерантности к представителям других этносов составляет 83,7\%. Это позволяет сделать вывод о позитивных результатах национальной и конфессиональной государственной политики и успешности внедрения казахстанской модели этноконфессионального согласия в рамках изучаемого временного этапа.

\section{ЛИТЕРАТУРА}


2. Н.А. Назарбаев - основоположник казахстанской модели межэтнического и межконфессионального согласия / сост.: А.Н. Нысанбаев, А.Г. Косиченко. Алматы, 2010. 365 с.

3. Кан Г.В. История Казахстана. Алматы, 2002. 222 с.

4. Акимбеков С.М. Афганский узел и проблемы безопасности Центральной Азии. Алматы, 2003. 400 с.

5. Ерекешева Л.Г. Религия и социально-культурные системы в истории Центральной Азии : автореф. дис. ... д-ра ист. наук. Алматы, 2008.49 с.

6. Султангалиева А.К. Эволюция ислама в Казахстане // Центральная Азия и Кавказ. 1999. № 5. С. 23-36.

7. Омаров С. Молодежь и религия // JambylTaraz. 2018. 7 февр. (№ 11). С. 8.

8. Конституция Республики Казахстан (принята 28 января 1993 г. Верховным Советом Республики Казахстан) // Ведомости Верховного Совета РК. 1993. № 3. Ст. 54.

9. Конституция Республики Казахстан (принята 30 августа 1995 г. на республиканском референдуме) // Ведомости Парламента РК. 1996. № 4. Ст. 217.

10. О свободе вероисповедания и религиозных объединениях: закон Республики Казахстан от 15 января 1992 года № 1128 -ХІІ // Ведомости Верховного Совета РК. 1992. № 4. Ст. 84.

11. Мейрманов Ж. Сохранить согласие и стабильность // Казахстанская правда. 2004. 16 февр.

12. Конусов Г.Т. Мусульманские религиозные институты в Казахстане: историко-религиоведческий анализ : автореф. дис. ... канд. филос. наук. Душанбе, 2012. 22 с.

13. Гражданский кодекс Республики Казахстан (принят 27 декабря 1994 года Верховным Советом Республики Казахстан) // Ведомости Верховного Совета РК. 1994. № 23-24 (приложение); 1995. № 15-16. Ст. 109; № 20. Ст. 121; Ведомости Парламента РК. 1996. № 2. Ст. 187.

14. Положение об Ассамблее народов Казахстана : Указ Президента РК от 7 сентября 2011 г. № 149. URL: https://assembly.kz/ank/ofitsialnyedokumenty/polozhenie-ob-assamblee-naroda-kazahstana/

15. O мерах по предупреждению и пресечению проявлений терроризма и экстремизма : Указ Президента PK от 10 февраля 2000 г. № 332 . URL: https://online.zakon.kz/document/?doc id=1016680

16. Ахметова Л. Казахстан в межкультурном диалоге: инициативы, личности и передовой опыт // Межкультурный диалог и культурное разнообразие. Алматы, 2007. 316 с.

17. Послание Президента Республики Казахстан H.A. Назарбаева народу Казахстана «Нұрлы жол - путь в будущее». 11 ноября 2014 г. URL: http://www.akorda.kz/ru/addresses/poslanie-prezidenta-respubliki-kazahstan-nnazarbaeva-narodu-kazahstana-11-noyabrya-2014-g

18. Официальный сайт Митрополичьего округа в Республике Казахстан «Православие в Казахстане». URL: http://mitropolia.kz

19. Рысбекова Ш.С. Деятельность Русской православной церкви в постсоветский период в Казахстане // Вестник Казахского национального университета. Сер. Религиозные исследования. 2015. № 1 (1). С. 96-103.

20. Интервью с митрополитом Астанайским и Казахстанским Александром. 14 марта 2015 г. // Православие и мир. URL: http://www.pravmir.ru/mitropolit-astanayskiy-i-kazahstanskiy-aleksandr-vsyakiy-moy-den-nachinaetsya-i-zavershaetsya-molitvoy-o-kazahstane/

21. Доклад митрополита Астанайского и Казахстанского Александра на епархиальном собрании. 12 декабря 2017 г. URL: http://miloserdiedobro.kz/story/doklad-mitropolita-astanaiskogo-i-kazakhstanskogo-aleksandra-na-eparkhialnom-sobranii-12-dekab

22. Амандыкова С.К., Искакова И.Е. Правовое регулирование деятельности религиозных объединений в Республике Казахстан: современное состояние и накопленный опыт // Вестник Карагандинского государственного университета. 2015. URL: https://articlekz.com/article/11678

23. Религиозные объединения в Казахстане / Международный центр культур и религий Комитета по делам религий Министерства культуры и спорта Республики Казахстан. Астана, 2015. 42 с.

24. Иванов В.А., Трофимов Я.Ф. Религии в Казахстане. Алматы, 2003. 238 с.

25. Лама Шариф К. Выступление председателя Агентства РК по делам религий на брифинге «Религиозная ситуация в Казахстане»: фрагмент стенограммы. URL: religiopolis.org/document/6274-religioznaja

26. Дашковский П.К., Жанбасинова А.С., Шершнева Е.А. Современные этноконфессиональные процессы в Восточном Казахстане // Религиозный ландшафт Западной Сибири и сопредельных регионов Центральной Азии. Т. 3: Конец XX - начало XXI в. Барнаул, 2017. С. 147-163.

27. Государственно-конфессиональные отношения в Республике Казахстан. Астана, 2014. 113 с.

28. О религиозной деятельности и религиозных объединениях: Закон Республики Казахстана от 11 октября 2011 г. № 483-IV. URL:https://online.zakon.kz/Document/?doc id=31067690

29. Амандыкова С.К., Искакова И.Е. Правовое регулирование деятельности религиозных объединений в Республике Казахстан: современное состояние и накопленный опыт // Вестник Карагандинского государственного университета. 2015. URL: https:/articlekz.com/article/11678.

30. Ситуация в религиозной сфере Казахстана. URL: http://www.ca-portal.ru/article:35663.

31. Шибунов М., Шибутова Л. Религиозные объединения в стране с точки зрения статистики с 2011 по 2017 год. URL: https://regnum.ru/news/2288695.html.

32. Международный отчет Казахстана о свободе вероисповедания за 2015 год. Государственный департамент США. Бюро по вопросам демократии, прав человека и труда. URL: https://kz.usembassy.gov/ru/kazakhstan-2015-international-religious-freedom-report-ru/

33. Итоги Национальной переписи населения PK. 2009. URL: http://stat.gov.kz/faces/wcnav_externalId/p_perepis?_afrLoop= 9727890322805927\#\%40\%3F_afrLoop\%3D9727890322805927\%26_adf.ctrl-state\%3Dlh8e3ywkw_38

34. Религиозная ситуация в Казахстане. URL: http://www.kazembassy.ru/rus/respublika kazakhstan/obshaya informaciya/

35. Государственная программа по противодействию религиозному экстремизму и терроризму в Республике Казахстан на $2013-2017$ годы. URL: http://adilet.zan.kz/rus/docs/U1300000648

36. Концепция государственной политики в религиозной сфере Республики Казахстан на 2017-2020 годы. URL: http://adilet.zan.kz/rus/docs/U1700000500

37. Интервью с председателем Комитета по делам религий Министерства по делам религий и гражданского общества Республики Казахстан Е.А. Онгарбаевым. 23.11.2017. URL: http:/ctc-rk.kz.председатель-комитета-по-делам-религ.html

38. Джалилов 3.Г. Возрождение религии и формирование государственно-конфессиональных отношений в современном Казахстане // Народы и религии Евразии. Барнаул, 2017. Вып. 3-4 (12-13). С. 110-121.

Vladislav A. Ovchinnikov. Kemerovo State University (Kemerovo, Russia). E-mail: rpcsib@rambler.ru

KAZAKHSTAN MODEL OF ETHNO-CONFESSIONAL CONSENT

Key words: ethno-confessional consent, model, poly-confessional, Kazakhstan, Islam, Russian Orthodox Church.

The article presents the results of a study aimed at identifying common trends and features of the creation and functioning of the model of ethnic and religious harmony in Kazakhstan. The source base of the study was a complex of published free sources: normative-legal acts, program and administrative documents, documents of office work, methodical recommendations of public authorities and religious organizations, statistical reports, materials of secular and Church periodical press. The development of a special model was due to the threat of socio-political stability, a sharp change in the ethnic and religious structure of the population in the post-Soviet period, multinational and multi-religious nature of the state. The process of creating a legislative and institutional framework for the model was complicated by the activation of groups representing radical Islamic movements and new "non-traditional" religions that used opposition forces. At the end of the XX century, Islam in the region was revived and on its basis in many states attempts were made to form a new cultural and value system, while Muslim communities began to develop beyond state control and borders. 
The author gave a detailed description of the place and role of the Russian Orthodox Church (hereinafter - ROC) in the functioning of the model, revealed the mechanism of interaction between the state and religious organizations, described the current religious situation, described the problems and made a forecast of the possible development of the situation. ROC in Kazakhstan is a "Russian factor of influence": a tool to support the Russian population, the spread of Russian culture and language, which is why it commands the continued support of the leadership of the Russian Federation. The leadership of Kazakhstan successfully uses the ROC in domestic policy as a tool for modernization of the current model of interethnic and interreligious harmony in the state, as well as in foreign policy as one of the points of strengthening good-neighborly relations with Russia. But there is a high probability of limiting the rights of the Russian population and changing the attitude to the ROC by the ruling elites in the event of the victory of opposition parties, whose ideology is based on the "Kazakh national idea" (or the idea of "ethno-cultural nationalism").

At the studied stage, the model has shown its effectiveness in solving the problems of development of the state and society. The main trend in the creation of the model was the strengthening of the role of the state in the management of the religious sphere and the introduction of restrictive rules. The peculiarity of the model is the reliance on traditional Islam and balancing between the interests of the Kazakh population, mainly professing Islam, and other nationalities through active interaction of the state with Christian and other religious organizations. The existing model contains a contradiction between the priority of one religion and nationality and the Declaration of the creation of a new civil-national identity. The authority of the President of Kazakhstan N. A. Nazarbayev allows to maintain balance. The changes in the political life of the state taking place in 2019 will be a serious test of the model for viability and efficiency.

\section{REFERENCES}

1. The Agency of the Republic of Kazakhstan on Statistics. Official website. [Online] Available from: http://stat.gov.kz.

2. Nysanbaev, A.N. \& Kosichenko, A.G. (2010) N.A. Nazarbaev - osnovopolozhnik kazakhstanskoy modeli mezhetnicheskogo i mezhkonfessional'nogo soglasiya [N.A. Nazarbayev - the founder of the Kazakhstani model of interethnic and interfaith harmony]. Almaty: [s.n.].

3. Kan, G.V. (2002) Istoriya Kazakhstana [History of Kazakhstan]. Almaty: Baspasy.

4. Akimbekov, S.M. (2003) Afganskiy uzel i problemy bezopasnosti Tsentral'noy Azii [The Afghan Knot and Central Asian Security Issues]. Almaty: [s.n.].

5. Erekesheva, L.G. (2008) Religiya i sotsial'no-kul'turnye sistemy v istorii Tsentral'noy Azii [Religion and socio-cultural systems in the history of Central Asia]. Abstract of History Dr. Diss. Almaty.

6. Sultangalieva, A.K. (1999) Evolyutsiya islama v Kazakhstane [Evolution of Islam in Kazakhstan]. Tsentral'naya Aziya i Kavkaz - Central Asia and the Caucasus. 5. pp. 23-36.

7. Omarov, S. (2018) Molodezh' i religiya [Youth and religion]. JambylTaraz. 7th February. pp. 8.

8. Konstitutsiya Respubliki Kazakhstan (prinyata 28 yanvarya 1993 g. Verkhovnym Sovetom Respubliki Kazakhstan). Vedomosti Verkhovnogo Soveta RK. 1993. № 3. St. 54

9. The Republic of Kazakhstan. (1996) Konstitutsiya Respubliki Kazakhstan (prinyata 30 avgusta 1995 g. na respublikanskom referendume) [The Constitution of the Republic of Kazakhstan (adopted on August 30, 1995, at a republican referendum)]. Vedomosti Parlamenta RK. 4. Art. 217.

10. The Republic of Kazakhstan. (1992) O svobode veroispovedaniya i religioznykh ob"edineniyakh: zakon Respubliki Kazakhstan ot 15 yanvarya 1992 goda № 1128-XII [On freedom of religion and religious associations: Law No. 1128-XII of the Republic of Kazakhstan dated January 15, 1992]. Vedomosti Verkhovnogo Soveta RK. 4. Art. 84.

11. Meyrmanov, Zh. (2004) Sokhranit' soglasie i stabil'nost' [To maintain harmony and stability]. Kazakhstanskaya pravda. 16th February.

12. Konusov, G.T. (2012) Musul'manskie religioznye instituty v Kazakhstane: istoriko-religiovedcheskiy analiz [Muslim Religious Institutions in Kazakhstan: Historical and Religious Studies]. Abstract of Philosophy Cand. Diss. Dushanbe.

13. The Republic of Kazakhstan. (1994) Grazhdanskiy kodeks Respubliki Kazakhstan (prinyat 27 dekabrya 1994 goda Verkhovnym Sovetom Respubliki Kazakhstan) [Civil Code of the Republic of Kazakhstan (adopted December 27, 1994 by the Supreme Council of the Republic of Kazakhstan)]. Vedomosti Verkhovnogo Soveta RK. 23-24.

14. The Republic of Kazakhstan. (2011) Polozhenie ob Assamblee narodov Kazakhstana: ukaz Prezidenta RK ot 7 sentyabrya 2011 g. № 149 [Regulation on the Assembly of the Peoples of Kazakhstan. Decree No. 149 of the President of the Republic of Kazakhstan dated September 7, 2011] [Online] Available from: https://assembly.kz/ank/ofitsialnye-dokumenty/polozhenie-ob-assamblee-naroda-kazahstana/

15. The Republic of Kazakhstan. (2000) O merakh po preduprezhdeniyu i presecheniyu proyavleniy terrorizma i ekstremizma: ukaz Prezidenta RK ot 10 fevralya $2000 \mathrm{~g}$. № 332 [On measures to prevent and suppress manifestations of terrorism and extremism: Decree No. 332 of the President of the Republic of Kazakhstan dated February 10, 2000]. [Online] Available from:https://online.zakon.kz/document/?doc_id=1016680.

16. Akhmetova, L. (2007) Kazakhstan v mezhkul'turnom dialoge: initsiativy, lichnosti i peredovoy opyt [Kazakhstan in intercultural dialogue: initiatives, individuals and best practices]. In: Abuseitova, M. Isak, K. \& Erekesheva, L. (eds) Mezhkul'turnyy dialog i kul'turnoe raznoobrazie [Intercultural Dialogue and Cultural Diversity]. Almaty: Daik-Press.

17. The Republic of Kazakhstan. (2014) Poslanie Prezidenta Respubliki Kazakhstan N. A. Nazarbaeva narodu Kazakhstana “Nłrly zhol-put'v budushchee". 11 noyabrya 2014 g. [Address from the President of the Republic of Kazakhstan N.A. Nazarbayev to the people of Kazakhstan "Nurly Zhol The Way to the Future". November 11, 2014]. [Online] Available from: http://www.akorda.kz/ru/addresses/poslanie-prezidenta-respublikikazahstan-nnazarbaeva-narodu-kazahstana-11-noyabrya-2014-g.

18. The Official Website of the Metropolitan Okrug in the Republic of Kazakhstan "Orthodoxy in Kazakhstan". [Online] Available from: http://mitropolia.kz.

19. Rysbekova, Sh.S. (2015) Deyatel'nost' Russkoy Pravoslavnoy Tserkvi v postsovetskiy period v Kazakhstane [The activities of the Russian Orthodox Church in the post-Soviet period in Kazakhstan]. Vestnik Kazakhskogo Natsional'nogo Universiteta. Seriya: Religioznye issledovaniya. 1(1). pp. 96103.

20. Metropolitan of Astana and Kazakhstan Alexander. (2015) Interv'yu s mitropolitom Astanayskim i Kazakhstanskim Aleksandrom. 14 marta 2015 g. [Interviews with Metropolitan of Astana and Kazakhstan Alexander. March 14, 2015]. [Online] Available from: http://www.pravmir.ru/mitropolitastanayskiy-i-kazahstanskiy-aleksandr-vsyakiy-moy-den-nachinaetsya-i-zavershaetsya-molitvoy-o-kazahstane/

21. Metropolitan of Astana and Kazakhstan Alexander. (2017) Doklad mitropolita Astanayskogo i Kazakhstanskogo Aleksandra na eparkhial'nom sobranii. 12 dekabrya $2017 \mathrm{~g}$. [Report of the Metropolitan of Astana and Kazakhstan, Alexander at the diocesan meeting. December 12, 2017]. [Online] Available from: http://miloserdie-dobro.kz/story/doklad-mitropolita-astanaiskogo-i-kazakhstanskogo-aleksandra-na-eparkhialnom-sobranii12-dekab

22. Amandykova, S.K. \& Iskakova, I.E. (2015) Pravovoe regulirovanie deyatel'nosti religioznykh ob"edineniy v Respublike Kazakhstan: sovremennoe sostoyanie i nakoplennyy opyt [Legal regulation of the activities of religious associations in the Republic of Kazakhstan: current status and experience]. [Online] Available from: https://articlekz.com/article/11678

23. International Center for Cultures and Religions of the Committee on Religious Affairs of the Ministry of Culture and Sports of the Republic of Kazakhstan. (2015) Religioznye ob"edineniya v Kazakhstane [Religious associations in Kazakhstan]. Astana: [s.n.].

24. Ivanov, V.A. \& Trofimov, Ya.F. (2003) Religii v Kazakhstane [Religions in Kazakhstan]. Almaty: [s.n.]. 
25. Lama Sharif, K. (n.d.) Vystuplenie predsedatelya agentstva RK po delam religiy na brifinge "Religioznaya situatsiya $v$ Kazakhstane” [Speech by the Chairman of the Agency for Religious Affairs of the Republic of Kazakhstan at the briefing "Religious Situation in Kazakhstan"]. [Online] Available from: religiopolis.org/document/6274-religioznaja

26. Dashkovsky, P.K., Zhanbasinova, A.S. \& Shershneva, E.A. (2017) Sovremennye etnokonfessional'nye protsessy v Vostochnom Kazakhstane [Modern ethno-confessional processes in East Kazakhstan]. In: Dashkovsky, P.K. (ed.) Religioznyy landshaft Zapadnoy Sibiri i sopredel'nykh regionov Tsentral'noy Azii [Religious landscape of Western Siberia and adjacent regions of Central Asia]. Vol. 3. Barnaul: Altai State University. pp. 147163.

27. Anon. (2014) Gosudarstvenno-konfessional'nye otnosheniya v Respublike Kazakhstan [The state-confessional relations in the Republic of Kazakhstan]. Astana: [s.n.].

28. The Republic of Kazakhstan. (2011) O religioznoy deyatel'nosti i religioznykh ob"edineniyakh: zakon Respubliki Kazakhstana ot 11 oktyabrya 2011 g. № 483-IV [On religious activities and religious associations: Law No. 483-IV of the Republic of Kazakhstan dated October 11, 2011]. [Online] Available from:https://online.zakon.kz/Document/?doc id=31067690

29. Amandykova, S.K. \& Iskakova, I.E. (2015) Pravovoe regulirovanie deyatel'nosti religioznykh ob"edineniy v Respublike Kazakhstan: sovremennoe sostoyanie $i$ nakoplennyy opyt [Legal regulation of the activities of religious associations in the Republic of Kazakhstan: current status and experience]. [Online] Available from: https://articlekz.com/article/11678

30. Shibutov, M. \& Shibutova, L. (2017) Situatsiya v religioznoy sfere Kazakhstana [The situation in the religious sphere of Kazakhstan]. [Online] Available from: http://www.ca-portal.ru/article:35663

31. Shibutov, M. \& Shibutova, L. (2017) Religioznye ob"edineniya v strane s tochki zreniya statistiki s 2011 po 2017 god [Religious associations in the country in terms of statistics from 2011 to 2017]. [Online] Available from: https://regnum.ru/news/2288695.html

32. US Department of State. Bureau for Democracy, Human Rights, and Labor. (2015) Mezhdunarodnyy otchet Kazakhstana o svobode veroispovedaniya za 2015 god [The international report of Kazakhstan on religious freedom for 2015]. [Online] Available from: https://kz.usembassy.gov/ru/kazakhstan-2015-international-religious-freedom-report-ru/

33. The Republic of Kazakhstan. (2009) Itogi Natsional'noy perepisi naseleniya RK. 2009 [The results of the National census of the Republic of Kazakhstan. 2009]. [Online] Available from:http://stat.gov.kz/faces/wcnav_externalId/p_perepis?_afrLoop=9727890322805927\#\% 40\%3F afrLoop\%3D9727890322805927\%26 adf.ctrl-state\%3Dlh8e3ywkw 38

34. The Kazakhstan Embassy in Russia. (n.d.) Religioznaya situatsiya v Kazakhstane [Religious situation in Kazakhstan]. [Online] Available from: http://www.kazembassy.ru/rus/respublika kazakhstan/obshaya informaciya/

35. The Republic of Kazakhstan. (n.d.) Gosudarstvennaya programma po protivodeystviyu religioznomu ekstremizmu i terrorizmu v Respublike Kazakhstan na 2013-2017 gody [State program on combating religious extremism and terrorism in the Republic of Kazakhstan for 2013-2017]. [Online] Available from:http://adilet.zan.kz/rus/docs/U1300000648.

36. Kontseptsiya gosudarstvennoy politiki v religioznoy sfere Respubliki Kazakhstan na 2017-2020 gody [The concept of the state policy in the religious sphere of the Republic of Kazakhstan for 2017-2020] [Elektronnyy resurs]. [Online] Available from:http://adilet.zan.kz/rus/docs/U1700000500

37. Ongarbaev, E.A. (2017) Interv'yu s predsedatelem komiteta po delam religiy Ministerstva po delam religiy i grazhdanskogo obshchestva Respubliki Kazakhstan E.A. Ongarbaevym. 23.11.2017 [Interview with the Chairman of the Committee on Religious Affairs of the Ministry of Religious Affairs and Civil Society of the Republic of Kazakhstan E.A. Ongarbayev. November 23, 2017]. [Online] Available from: http://ctc-rk.kz.predsedatel'komiteta-po-delam-relig.html

38. Dzhalilov, Z.G. (2017) Vozrozhdenie religii i formirovanie gosudarstvenno-konfessional'nykh otnosheniy v sovremennom Kazakhstane [The revival of religion and the formation of state-confessional relations in modern Kazakhstan]. Narody i religii Evrazii - Nations and Religions of Eurasia. 3 (12-13). pp. 110-121. 